OPEN ACCESS

Edited by:

Amalia Yanni,

Harokopio University, Greece

Reviewed by:

Leticia Abecia,

University of the Basque

Country, Spain

Ahmad Ud Din,

Southwest Medical University, China

*Correspondence:

Xiangshu Piao

piaoxsh@cau.edu.cn

Specialty section: This article was submitted to

Nutrition and Microbes,

a section of the journal

Frontiers in Nutrition

Received: 27 February 2021 Accepted: 06 May 2021

Published: 05 August 2021

Citation:

Ma J, Mahfuz S, Wang J and Piao X (2021) Effect of Dietary

Supplementation With Mixed Organic Acids on Immune Function, Antioxidative Characteristics, Digestive Enzymes Activity, and Intestinal Health in Broiler Chickens.

Front. Nutr. 8:673316. doi: 10.3389/fnut.2021.673316

\section{Effect of Dietary Supplementation With Mixed Organic Acids on Immune Function, Antioxidative Characteristics, Digestive Enzymes Activity, and Intestinal Health in Broiler Chickens}

\author{
Jiayu Ma, Shad Mahfuz, Jian Wang and Xiangshu Piao* \\ State Key Laboratory of Animal Nutrition, College of Animal Science and Technology, China Agricultural University, Beijing, \\ China
}

The purpose of this study was to explore the effect of dietary supplementation with mixed organic acids on intestinal health, enzyme activity, and antioxidative characteristics in broilers. A total of 192 1-day-old chicks were evenly allocated to three experimental groups with eight replicates, a basal diet with 0 (Control), 3,000 mg/kg (LMOA), 6,000 $\mathrm{mg} / \mathrm{kg}(\mathrm{HMOA})$ mixed organic acid. The tissue and serum samples were gathered on 21 and $42 \mathrm{~d}$ of the experiment. An increased $(P<0.05)$ concentration of IgA, D-lactate (D-LA), and interleukin-10 (IL-10) in the serum of broilers diets with HMOA was observed. The levels of total antioxidant capacity (T-AOC) and catalase activity (CAT) in serum were enhanced $(P<0.05)$ with dietary and mixed organic acid, respectively, and increased $(P<0.05)$ content of superoxide dismutase (SOD) and CAT in the duodenum of broilers diets with LMOA was noticed. Also, LMOA decreased $(P<0.05)$ the $\mathrm{pH}$ value of the duodenum and enhanced $(P<0.05)$ the amylase activity of the pancreas, the tight junction protein (mainly Claudin-1, Claudin-2, and ZO-1) in the duodenum of broilers fed with mixed organic acid were promoted $(P<0.05)$, and the LMOA group performed better in the small intestine. In cecum microbiota, LMOA and HMOA modulated the structure of microbiota and mainly reduced the relative abundance of Escherichia coli. In brief, dietary supplemented mixed organic acid improved the health status of broilers by promoting the immune function, enhancing the antioxidative characteristics and tight junction proteins expression as well as cecum microbiota. However, LMOA groups may be a better fit considering the comprehensive effects of experiments and economic costs.

Keywords: mixed organic acid, antioxidative characteristics, tight junction, intestinal health, broiler

\section{INTRODUCTION}

With the accelerating industrialization of livestock farming and the increasing attention paid to food safety, companies are increasingly concerned about the problems associated with applying antibiotics in feed, such as drug resistance in pathogenic bacteria and drug residues in livestock products (1). Thus, reducing the application of antibiotics in feeds and finding alternatives is 
imperative to control the occurrence of diseases in livestock and reduce the harmful effects of antibiotics on humans. Consequently, the development and application of new green additives have emerged as a hot issue in feed research and industry (2). Mixed organic acids (MOA) are favored by feed and livestock enterprises because of their advantages of improving the growth performance and intestinal health of livestock, as well as the benefits of the three-free (i.e., drug resistancefree, residue-free, and pollution-free), which make the MOA the most promising green alternatives to antibiotics $(3,4)$. Numerous studies concentrated on the growth performance, diarrhea rate, the digestibility of nutrients, and intestinal health in swine (5-8) and poultry (9-11). However, limited literature has focused on the effects of high levels of MOA in diets on immune function, antioxidant properties, digestive enzymes activity as well as intestinal health of the broiler chickens. The objective of this experiment was to evaluate the effects of high and low levels of mixed organic acids in corn-soybean meal diets on immune parameters, antioxidant properties of serum and intestine, gastrointestinal enzyme activities, and intestinal health of broiler chickens to systematically and comprehensively assess the feeding effectiveness of mixed organic acids and understand the specific mechanism of organic acids as well as to provide a theoretical basis for researchers to analyze the feasibility of replacing antibiotics with mixed organic acid in livestock farming.

\section{MATERIALS AND METHODS}

This study was carried out in an experimental poultry shed at China Agricultural University. The proceedings of this research were licensed by the Institutional Animal Care and Use Committee of China Agricultural University (No.AW090891041, Beijing, China).

\section{Mixed Organic Acid Products}

The mixed organic acid product named Fysal MP (product code: 2017SZ34) employed in the present study was sourced from Nutreco (Amsterdam, Netherlands), and it primarily contains formic acid $(\geq 11 \%)$, formate ammonia $(\geq 13 \%)$, propionate $(\geq 10 \%)$, acetate $(\geq 5.1 \%)$, lactate $(\geq 4.2 \%)$, and other organic acids with lower concentrations $(\leq 2 \%)$, such as malic acid and citric acid. The carrier is silica.

\section{Experimental House and Management}

The poultry shed was designed with forced ventilation, radiant heating, and illumination. The chicks were housed in an average of 24 wire-mesh cages, each equipped with three automatic teat waterers and a round feeder (diameter: $37 \mathrm{~cm}$ ), which provided $24 \mathrm{~h}$ of continuous light for the first 2 days before the chicks reached the poultry house. Thereafter, a 23-light:1-dark lighting regimen was implemented daily. During the 1 st week of the experiment, the temperature was controlled at $34-35^{\circ} \mathrm{C}$ and gradually lowered by $1-2^{\circ} \mathrm{C}$ per week until the temperature was $25 \pm 1^{\circ} \mathrm{C}$ while the relative humidity was held at $45-55 \%$. All chicks were vaccinated with Newcastle disease and infectious bronchitis vaccine (LASOTA $+\mathrm{H}_{120}$, supplied by Qilu Animal
TABLE 1 | Composition and nutrient levels of basal diets ( $\mathrm{DM}^{\mathrm{a}}$ basis).

\begin{tabular}{|c|c|c|}
\hline Ingredients (\%) & $\begin{array}{c}\text { Phase } 1 \text { (d } 1 \text { to } d \\
\text { 21) }\end{array}$ & $\begin{array}{c}\text { Phase } 2 \text { (d } 22 \text { to } \\
\text { d 42) }\end{array}$ \\
\hline Corn, $8.2 \% \mathrm{CP}^{\mathrm{a}}$ & 61.74 & 65.17 \\
\hline Soybean meal, $46 \% \mathrm{CP}$ & 28.50 & 24.50 \\
\hline Fish meal, $64.7 \% \mathrm{CP}$ & 3.29 & 3.33 \\
\hline Soy oil & 2.90 & 3.81 \\
\hline Dicalcium phosphate & 1.30 & 1.20 \\
\hline Limestone & 1.28 & 1.10 \\
\hline Salt & 0.30 & 0.30 \\
\hline L-lysine $\mathrm{HCl}, 78 \%$ & 0.00 & 0.00 \\
\hline DL-Methionine, 98\% & 0.15 & 0.05 \\
\hline L-Threonine, 98\% & 0.04 & 0.04 \\
\hline Vitamin-mineral premix ${ }^{b}$ & 0.50 & 0.50 \\
\hline Total & 100 & 100 \\
\hline \multicolumn{3}{|l|}{ Nutritional levels ${ }^{c}$} \\
\hline Metabolizable energy, kcal/kg & $3,050.73$ & $3,150.11$ \\
\hline Crude protein & 20.68 & 19.06 \\
\hline Calcium & 1.02 & 0.91 \\
\hline Digestible phosphorus & 0.43 & 0.40 \\
\hline Standardized ileal digestible lysine & 0.80 & 0.72 \\
\hline Standardized ileal digestible methionine & 0.27 & 0.25 \\
\hline Standardized ileal digestible threonine & 0.58 & 0.53 \\
\hline
\end{tabular}

${ }^{a} D M$, dry matter; $C P$, crude protein.

${ }^{b}$ Premix provided the following per $\mathrm{kg}$ of feed: vitamin $\mathrm{A}, 10,000 \mathrm{IU}$; vitamin $D_{3}, 3,000 \mathrm{IU}$; vit-amin $E, 24 \mathrm{mg}$; vitamin $K_{3}, 2.1 \mathrm{mg}$; vitamin $B_{12}, 2 \mathrm{mg}$; riboflavin, $5.0 \mathrm{mg}$; pantothenic acid, $15 \mathrm{mg}$; niacin, $40 \mathrm{mg}$; choline chloride, $500 \mathrm{mg}$; folic acid, $0.9 \mathrm{mg}$; vitamin $B_{6}$, $3.0 \mathrm{mg}$; biotin, $0.05 \mathrm{mg}$; $\mathrm{Mn}$ (from $\mathrm{MnSO}_{4} \cdot \mathrm{H}_{2} \mathrm{O}$ ), $70 \mathrm{mg}$; $\mathrm{Fe}$ (from $\mathrm{FeSO}_{4} \cdot \mathrm{H}_{2} \mathrm{O}$ ), $80 \mathrm{mg}$; $\mathrm{Zn}$ (from $\mathrm{ZnSO}_{4} \cdot \mathrm{H}_{2} \mathrm{O}$ ), $100 \mathrm{mg}$; $\mathrm{Cu}$ (from $\mathrm{CuSO}_{4} \cdot 5 \mathrm{H}_{2} \mathrm{O}$ ), $18.8 \mathrm{mg}$; I (from KI), $0.35 \mathrm{mg}$; $\mathrm{Se}$ (from $\mathrm{Na}_{2} \mathrm{SeO}_{3}$ ), $0.30 \mathrm{mg}$.

${ }^{c}$ The metabolizable energy and crude protein in nutrient levels were analyzed values, other nutrients were cacluated values.

Health Products Co., Ltd. Shandong, China) at d 7, d 14, and d 21 (the first two times by injection and the third time by mixing with drinking water), respectively.

\section{Chicks, Diets, and Experimental Procedures}

A total of 192 1-day-old male chicks weighing $48.40 \pm 0.64 \mathrm{~g}$ were obtained from commercial hatcheries (Arbor Acres Poultry Breeding Company, Beijing, China) and transferred to the experimental house in a van within $30 \mathrm{~min}$ at $35^{\circ} \mathrm{C}$. After, 1day-old male chicks were weighed on arrival at the experimental house and labeled with wing-rings. The chicks were randomly distributed into three experimental groups with eight replicates (cages) to receive a basal diet of corn-soybean meal supplemented with 0 (Ctrl), 3,000 mg/kg (low mixed organic acids, LMOA), and $6,000 \mathrm{mg} / \mathrm{kg}$ (high mixed organic acids, HMOA) of MOA, respectively. In total, eight replicates (cages) with eight chicks per treatment were designated for the present study. Table 1 lists the composition and nutritional levels of basal diets, which satisfied or excelled the NRC requirements. Additionally, the health status and the number of dead animals were observed and noted daily. 


\section{Sampling Procedure}

On the 21st and 42nd day, one broiler chicken with uniform weight was picked from each cage, respectively; $10 \mathrm{~mL}$ of the non-anticoagulant blood sample was drawn from the jugular vein into a vacutainer and placed at room temperature for $30 \mathrm{~min}$, centrifuged $3,000 \mathrm{rpm}$ at $4^{\circ} \mathrm{C}$ for $15 \mathrm{~min}$, and the serum was prepared and stored at $-20^{\circ} \mathrm{C}$ for the further determination of biochemical immune parameters.

Immediately after the chickens were slaughtered by cervical dislocation at the slaughterhouse, the gizzard, about $1 / 2$ of the posterior segment of duodenum, jejunum, and the ileum were collected. The contents of the intestines were diluted 1:8 with deionized water, vibrated, and mixed with a small oscillator $(250$ $\mathrm{r} / \mathrm{min}$ ) for $5 \mathrm{~min}$, then measured the $\mathrm{pH}$ value by a portable PHS-3C acidimeter (Precision Scientific Instruments Co., Ltd., Shanghai, China). Simultaneously, the liver, spleen, and pancreas samples were gathered to calculate the visceral weight index (Formulation: viscera weight index $(\%)=$ viscera weight/final body weight *100\%). Approximately $2 \mathrm{~cm}$ of jejunum, ileum, and duodenum at the $1 / 2$ of the posterior segment were taken and cleaned the intestinal chyme gently with $0.9 \%$ normal saline, and the intestinal sample was collected and stored at $-80{ }^{\circ} \mathrm{C}$ for determination of gene expression of tight junction protein and intestinal enzyme activity. Subsequently, we gathered the cecum chyme for the sequencing of the 16S rRNA gene.

\section{RNA Extraction and Real-Time Quantitative PCR}

The Trizol reagent (Tiangen Biotech, Beijing, China) was applied to extract the total RNA of the small intestine according to the manufacturer's specifications, the content and purity of RNA were determined using a NanoDrop 2000 spectrophotometer (Thermo Fisher Scientific, Waltham, USA), and the integrity was assessed by agarose gel electrophoresis using ethidium bromide staining. The RNA to be measured was reverse-transcribed into cDNA by TransScript All-in-One First-Strand cDNA Synthesis SuperMIX for qPCR kit (QIAGEN, Northwestern Hilden, Germany). The reverse transcription (RT) reaction was composed of $0.5 \mu \mathrm{g}$ total RNA, $5 \mu \mathrm{L} 5 \times$ TransScript All-in-one SuperMix for qPCR, $0.5 \mu \mathrm{L}$ gDNA Remover and $4 \mu \mathrm{L}$ nucleasefree water (total in $10 \mu \mathrm{L}$ ). The reactions were conducted with the GeneAmp ${ }^{\circledR}$ PCR System 9700 (Applied Biosystems, Waltham, USA) for $15 \mathrm{~min}$ at $42^{\circ} \mathrm{C}$ and $5 \mathrm{~s}$ at $85^{\circ} \mathrm{C}$. The 10 $\mu \mathrm{L}$ RT reaction mixture was subsequently diluted $\times 10$ with nuclease-free water and stored at $-20^{\circ} \mathrm{C}$. The LightCycler ${ }^{\circledR} 480$ II Real-time PCR Instrument (Roche, Basel, Swiss) was used and the PCR reaction mixture containing 3.6 $\mu \mathrm{L}$ nuclease-free water, $5 \mu \mathrm{L} 2 \times$ PerfectStart $^{\mathrm{TM}}$ Green qPCR Master Mix, $0.5 \mu \mathrm{L}$ forward primer $(10 \mu \mathrm{mol} / \mathrm{L}), 0.5 \mu \mathrm{L}$ reverse primer $(10 \mu \mathrm{mol} / \mathrm{L})$, and $1.0 \mu \mathrm{L}$ cDNA. Reaction conditions (PCR efficiency: 94$105 \%$ ) were $95^{\circ} \mathrm{C}$ and pre-denaturation for $1 \mathrm{~min}$, followed by 45 cycles (denatured at $95^{\circ} \mathrm{C}$ for $15 \mathrm{~s}$, annealed at $60^{\circ} \mathrm{C}$ for $30 \mathrm{~s}$, and then fluorescence collected). Also, the product specificity was detected using a melting curve at the end of the cycle: a slow ramp-up from $60^{\circ} \mathrm{C}$ to $97^{\circ} \mathrm{C}$ with five fluorescence signal acquisitions per degree Celsius. The primers were designed
TABLE 2 | Sequence and parameters of primers for PCR.

\begin{tabular}{|c|c|c|}
\hline Gene names & Primer sequence $\left(5^{\prime}-3^{\prime}\right)$ & Length (bp) \\
\hline GAPDH & $\begin{array}{l}\text { F: GAAGGCTGGGGCTCATCTG } \\
\text { R: CAGTTGGTGGTGCACGATG }\end{array}$ & 150 \\
\hline Occludin & $\begin{array}{l}\text { F: AGATGGACAGCATCAACG } \\
\text { R: CTGCCACATCCTGGTATT }\end{array}$ & 90 \\
\hline Claudin-1 & $\begin{array}{l}\text { F: CCTCCACAGGGAAGGATTAC } \\
\text { R: ACCTAGAGTCTGAACTCTGC }\end{array}$ & 121 \\
\hline Claudin-2 & $\begin{array}{l}\text { F: CTCAGCCCTCCATCAAACA } \\
\text { R: TGCTGCTGCTACACGTAT }\end{array}$ & 82 \\
\hline $\mathrm{ZO}-1$ & $\begin{array}{l}\text { F: TGGTACTGACCAACGTAGTTC } \\
\text { R: AGGAGTGACATCTAATAAAGCG }\end{array}$ & 94 \\
\hline $\mathrm{ZO}-2$ & $\begin{array}{l}\text { F: ATGATAGCTGGTATGGTAGTCT } \\
\text { R: CATGCGATCATCTGCGTC }\end{array}$ & 113 \\
\hline
\end{tabular}

$F$, forward primer; $R$, reverse primer.

and synthesized by Sangon Biotech (Shanghai, China) based on the mRNA sequences on the NCBI database (Table 2), the glyceraldehyde-3-phosphate dehydrogenase (GAPDH) gene was used as a housekeeping gene, the results of the relative quantitative expression were calculated using the comparative $\mathrm{Ct}$ methodology, the expression of the target gene was $2^{-\Delta \Delta \mathrm{Ct}}$ [ $\Delta \Delta \mathrm{Ct}=(\mathrm{Ct}$ target genes $-\mathrm{Ct}$ housekeeping genes $)$ experimental group( $\mathrm{Ct}$ target genes $-\mathrm{Ct}$ housekeeping genes $)$ control group], the analysis of all samples was repeated twice on the same PCR plate, and the data were averaged.

\section{Serum Biochemical Immunity and Intestinal Enzyme Activity}

Immunoglobulins (IgG, IgA), D-lactic acid (DLA), diamine oxidase (DAO), tumor necrosis factor- $\alpha$ (TNF- $\alpha)$, interleukin-1 $\beta$ (IL-1 $\beta$ ), interleukin-6 (IL-6), and interleukin-10 (IL-10) in serum were detected via ELISA methodology, and the enzyme activity of amylase (Iodine-starch), lipase (P-nitrophenol ester), trypsin (benzoyl-DL-arginine-p-nitroanilide), and chymotrypsin (Nglutaryl-L-phenylalanine-p-nitroaniline) in the small intestine were measured by immunoturbidimetric methodology. Contents of total antioxidant capacity (T-AOC), malondialdehyde (MDA), catalase (CAT), glutathione peroxidase (GSH-Px), and superoxide dismutase (SOD) in serum, duodenum, jejunum, and ileum were examined via spectrophotometry (PU 8720 UV/VIS Scanning Spectrophotometer, Pye Unicam, UK). The commercial assay kits were supplied by Nanjing Jiancheng Institute of Bioengineering (Nanjing, China), and all the procedures were conducted according to the protocol of the kits.

\section{Pyrosequencing of 16S rRNA Amplicons}

The cecum chyme was removed from the $-80^{\circ} \mathrm{C}$ refrigerator and total DNA of the microbial community was extracted according to the instructions of DNeasy ${ }^{\circledR}$ PowerSoil ${ }^{\circledR}$ Pro Kit (QIAGEN, Northwestern Hilden, Germany), and the quality and purity of DNA were detected using a NanoDrop 2000 UV spectrophotometer (USA) and 1\% agarose gel electrophoresis. The extracted DNA was diluted to $1 \mathrm{ng} / \mu \mathrm{L}$ with sterile water and used as a template for PCR amplification in the V3-V4 
TABLE 3 | Immune function of serum in 21-day and 42-day-old broilers as affected by dietary MOA supplementation.

\begin{tabular}{|c|c|c|c|c|c|c|c|}
\hline \multirow[t]{2}{*}{ Item } & \multirow[t]{2}{*}{ Ctrl ${ }^{\mathrm{a}}$} & \multirow[t]{2}{*}{ LMOA } & \multirow[t]{2}{*}{ HMOA } & \multirow[t]{2}{*}{ SEM } & \multicolumn{3}{|c|}{$P$-value } \\
\hline & & & & & ANOVA & Linear & Quadratic \\
\hline \multicolumn{8}{|l|}{$21 d$} \\
\hline $\lg A[u g / m L]$ & 11.65 & 11.33 & 11.50 & 0.73 & 0.95 & 0.88 & 0.79 \\
\hline $\operatorname{lgG}[\mathrm{ng} / \mathrm{L}]$ & 9.45 & 9.44 & 8.83 & 0.74 & 0.80 & 0.57 & 0.74 \\
\hline $\mathrm{D}-\mathrm{LA}[\mu \mathrm{mol} / \mathrm{L}]$ & $5.37^{b}$ & $8.87^{a}$ & $5.22^{b}$ & 0.44 & $<0.01$ & 0.81 & $<0.01$ \\
\hline DAO [U/mL] & 3.23 & 3.12 & 2.84 & 0.16 & 0.24 & 0.11 & 0.67 \\
\hline IL-1 $\beta$ [pg/mL] & 88.54 & 79.67 & 84.21 & 5.26 & 0.52 & 0.57 & 0.32 \\
\hline IL-6 [ng/L] & 29.02 & 28.61 & 27.01 & 1.38 & 0.57 & 0.33 & 0.73 \\
\hline IL-10 [pg/mL] & 12.06 & 12.46 & 11.13 & 0.56 & 0.27 & 0.27 & 0.23 \\
\hline TNF- $\alpha$ [ng/L] & 66.41 & 68.11 & 63.54 & 3.91 & 0.71 & 0.62 & 0.53 \\
\hline \multicolumn{8}{|l|}{$42 d$} \\
\hline $\lg \mathrm{A}[\mathrm{ug} / \mathrm{mL}]$ & $12.77^{b}$ & $13.29^{a, b}$ & $14.65^{a}$ & 0.48 & 0.05 & 0.02 & 0.49 \\
\hline $\lg G$ [ng/L] & 10.34 & 10.81 & 11.87 & 0.61 & 0.24 & 0.11 & 0.70 \\
\hline $\mathrm{D}-\llcorner\mathrm{A}[\mu \mathrm{mol} / \mathrm{L}]$ & $6.51^{b}$ & $6.75^{a, b}$ & $7.63^{\mathrm{a}}$ & 0.32 & 0.05 & 0.03 & 0.44 \\
\hline $\mathrm{DAO}[\mathrm{U} / \mathrm{mL}]$ & 3.92 & 3.61 & 4.02 & 0.22 & 0.41 & 0.74 & 0.20 \\
\hline IL-1 $\beta$ [pg/mL] & 96.03 & 100.65 & 105.54 & 4.68 & 0.39 & 0.18 & 0.98 \\
\hline IL-6 [ng/L] & 33.91 & 33.82 & 36.86 & 1.30 & 0.22 & 0.14 & 0.35 \\
\hline IL-10 [pg/mL] & $12.81^{b}$ & $13.81^{b}$ & $16.12^{\mathrm{a}}$ & 0.48 & $<0.01$ & $<0.01$ & 0.29 \\
\hline $\mathrm{TNF}-\alpha[\mathrm{ng} / \mathrm{L}]$ & 79.63 & 81.91 & 87.10 & 3.66 & 0.37 & 0.18 & 0.75 \\
\hline
\end{tabular}

${ }^{a-b}$ In each row, means with the same letter represented no significant differences.

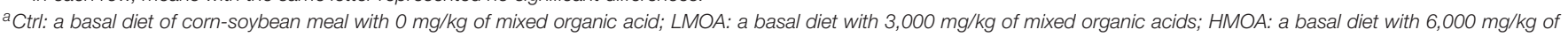
mixed organic acids. $n=8$.

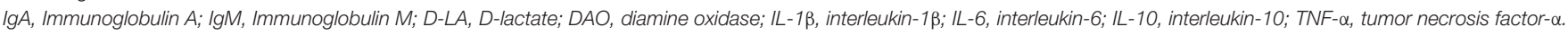

TABLE 4 | Offal organ weight in 21 and $42 \mathrm{~d}$ of broilers as affected by dietary MOA supplementation (\% of body weight).

\begin{tabular}{|c|c|c|c|c|c|c|c|}
\hline Item & $\mathrm{Ctrl}^{\mathrm{a}}$ & LMOA & HMOA & SEM & \multicolumn{3}{|c|}{$P$-value } \\
\hline \multicolumn{8}{|l|}{$21 \mathrm{~d}$} \\
\hline Spleen & 0.10 & 0.10 & 0.08 & 0.01 & 0.31 & 0.21 & 0.38 \\
\hline Pancreas & 0.32 & 0.30 & 0.29 & 0.02 & 0.58 & 0.32 & 0.80 \\
\hline Liver & 2.41 & 2.52 & 2.43 & 0.12 & 0.79 & 0.89 & 0.51 \\
\hline Spleen & 0.12 & 0.14 & 0.12 & 0.02 & 0.75 & 0.95 & 0.46 \\
\hline Pancreas & 0.17 & 0.20 & 0.20 & 0.02 & 0.30 & 0.19 & 0.40 \\
\hline Liver & 1.97 & 2.09 & 2.01 & 0.07 & 0.48 & 0.71 & 0.26 \\
\hline
\end{tabular}

${ }^{a-b}$ In each row means with the same letter represented no significant differences.

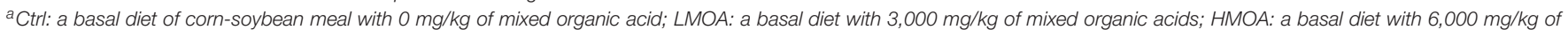
mixed organic acids. $n=8$.

variable region of the $16 \mathrm{~S}$ rRNA gene (12). Primer sequence: 338F (5'-ACTCCTACGGGAGGCAGCAG-3') and 806R (5'GGACTACHVGGGTWTCTAAT-3'). Amplification procedure: $95^{\circ} \mathrm{C}$ pre-denaturation for $3 \mathrm{~min}, 27$ cycles $\left(95^{\circ} \mathrm{C}\right.$ denaturation for $30 \mathrm{~s}, 55^{\circ} \mathrm{C}$ annealing for $30 \mathrm{~s}, 72^{\circ} \mathrm{C}$ extension for $30 \mathrm{~s}$ ), and then stable extension at $72^{\circ} \mathrm{C}$ for $10 \mathrm{~min}$. The final storage was performed at $4^{\circ} \mathrm{C}$ (PCR equipment: ABI GeneAmp ${ }^{\circledR}$ 9700, Shanghai Aiyan Biological Technology, China). The PCR reaction system was as follows: $5 \times$ TransStart FastPfu buffer $4 \mu \mathrm{L}, 2.5 \mathrm{mM}$ dNTPs $2 \mu \mathrm{L}$, upstream primer $(5 \mu \mathrm{M}) 0.8 \mu \mathrm{L}$, downstream primer $(5 \mu \mathrm{M}) 0.8 \mu \mathrm{L}$, TransStart FastPfu DNA polymerase $0.4 \mu \mathrm{L}$, template DNA $10 \mathrm{ng}$, and added doubledistilled water to $20 \mu \mathrm{L}$. The PCR products from the same sample were mixed and recovered using a $2 \%$ agarose gel, purified using the AxyPrep DNA Gel Extraction Kit (Axygen Biosciences, Union City, CA, USA), detected by $2 \%$ agarose gel electrophoresis, and quantified by Quantus ${ }^{\mathrm{TM}}$ Fluorometer (Promega, USA). The library construction was conducted by NEXTFLEX Rapid DNA-Seq Kit: (1) splice linkage; (2) removal of splice self-linked fragments using magnetic bead screening; 
(3) library template enrichment using PCR amplification; (4) recovery of PCR products by magnetic beads to obtain the final library. The quantification library was examined using a Qubit 2.0 fluorometer (Thermo Fisher Scientific, USA) to obtain a homogeneous concentration. Then sequenced on the Illumina's Miseq PE300 platform (Illumina, San Diego, USA) following the standard protocol to obtain $250 \mathrm{bp}$ paired-end reads, which were assembled and filtered by PANDAseq to remove the tags with more than three ambiguous bases as well as the average quality score $<20$. The Raw data were deposited and uploaded to the NCBI SRA database (sequence number: PRJNA719231).

\section{Statistical Analysis}

The raw data was preliminarily organized by Excel software (Microsoft, Redmond, USA). Data were analyzed by one-way ANOVA analysis using the GLM program of SAS 9.2 (SAS Institute Inc., Cary, NC, USA) in a completely randomized design. Each cage was used as an experimental unit for broiler growth performance, and the chosen broilers were considered as the experimental units for other properties. Duncan's multiple comparisons were used for analyzing differences between groups. The linear and quadratic comparisons were applied to identify the dose-effect of mixed organic acid in broiler chickens.

For microbiota profiling, the raw sequences of $16 \mathrm{~s}$ rRNA were quality-controlled using fastp (https://github.com/OpenGene/ fastp, version 0.20.0) software and spliced by FLASH (http:// www.cbcb.umd.edu/software/flash, version 1.2.10) software. The sequences were OTUs clustered and chimeras were removed based on $97 \%$ similarity using Uparse software (http://drive5. com/uparse/, version 7.1). Species classification annotation of each sequence was performed using Ribosomal Database Project (RDP) classifier (http://sourceforge.net/projects/rdp-classifier/, version 2.2), comparing to the Silva $16 \mathrm{~S}$ rRNA database (http:// www.arb-silva.de) and setting a comparison threshold at an 0.7 confidence level. The software used to analyze $\alpha$-diversity (the Shannon and Simpson indices represented the diversity of the intestinal microorganisms, while the Sobs, Ace, and Chao indices reflected the species richness) by mothur (http://www.mothur. org/wiki/, version 1.30.1) and $\beta$-diversity was evaluated using principal coordinate analysis (PCoA) by QIIME (University of California, San Diego, USA). Also, the results were plotted with the "vegan" and "ggplot2" packages by R software (Version 3.4.4). The significant differences in microbiological communities between groups were evaluated by ANOSIM with the R package "vegan." The Linear discriminant analysis (LDA) and effect size (LEfSe) analyses were operated via the LEfSe tool (Shanghai Majorbio Bio-pharm Technology, China). A $P$-value of $P<0.05$ was considered statistically significant and $0.05<P \leq 0.10$ was indicative of a differential trend.

\section{RESULTS}

\section{Immune Characteristics}

Dietary supplemented with LMOA increased $(P<0.05)$ the content of D-lactate (D-LA) in 21 d-broilers (Table 3). The highest concentrations of IgA, D-LA, and Interlukin-10 (IL10) were recorded for $42 \mathrm{~d}$-broilers supplementation with HMOA. However, in terms of other serum parameters, there were no significant differences between the treatment and the control group.

\section{Viscera Percentage}

Neither on day 21 nor day 42 of broilers were there any differences in spleen, pancreas, or liver weight percentage between the treatment and control (Table 4).

\section{Intestinal pH Value}

The diets supplemented with LMOA and HMOA decreased $(P<0.05)$ the $\mathrm{pH}$ values of the duodenum compared to the control and decline linearly (Table 5). However, there were no significant differences in the $\mathrm{pH}$ values of the gizzard, jejunum, and ileum.

\section{Antioxidant Enzyme Characteristics of Serum and Small Intestine}

High $(P<0.05)$ total antioxidant capacity compared to the control was observed (Figure 1) in serum gathered from $42 \mathrm{~d}$ broilers supplemented with the LMOA. The catalase activity of serum in $21 \mathrm{~d}$-broilers fed diets with HMOA was higher than in control. The superoxide dismutase activity and catalase activity were increased $(P<0.05)$ compared to the control at $42 \mathrm{~d}$ broilers fed with LMOA and HMOA, respectively. The total antioxidant capacity and the amount of malondialdehyde were not affected by supplementing with LMOA and HMOA.

High $(P<0.05)$ superoxide dismutase activity and catalase activity were found in the duodenum of broilers dietary

TABLE 5 | The $\mathrm{pH}$ value of gut in $42 \mathrm{~d}$-broilers as affected by dietary MOA supplementation.

\begin{tabular}{|c|c|c|c|c|c|c|c|}
\hline \multirow[t]{2}{*}{ Item } & \multirow[t]{2}{*}{ Ctrl $^{\mathrm{a}}$} & \multirow[t]{2}{*}{ LMOA } & \multirow[t]{2}{*}{ HMOA } & \multirow[t]{2}{*}{ SEM } & \multicolumn{3}{|c|}{$P$-value } \\
\hline & & & & & ANOVA & Linear & Quadratic \\
\hline Gizzard & 4.17 & 3.96 & 3.86 & 0.18 & 0.49 & 0.25 & 0.81 \\
\hline Duodenum & $5.99^{a}$ & $5.64^{b}$ & $5.49^{b}$ & 0.08 & $<0.01$ & $<0.01$ & 0.32 \\
\hline Jejunum & 5.68 & 5.96 & 5.83 & 0.07 & 0.06 & 0.16 & 0.05 \\
\hline Ileum & 6.07 & 6.23 & 6.00 & 0.14 & 0.31 & 0.73 & 0.15 \\
\hline
\end{tabular}

${ }^{a-b}$ In each row means with the same letter represented no significant differences.

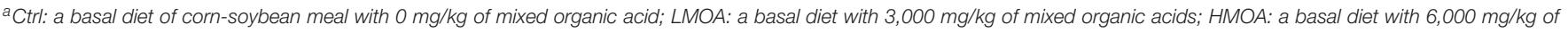
mixed organic acids. $n=8$. 




supplemented with LMOA compared to the control group (Figure 2). The glutathione peroxidase activity, total antioxidant capacity, and amount of malondialdehyde were not influenced in the duodenum, jejunum, and ileum by feeding LMOA and HMOA.

\section{Digestive Enzyme Activity}

The LMOA-supplemented diet increased $(P<0.05)$ the amylase activity in the pancreas of $42 \mathrm{~d}$-broilers (Figure 3). However, the activity of trypsin, lipase, and chymotrypsin in the pancreas, duodenum, jejunum, and ileum of broilers was not observed any significant difference by feeding LMOA and HMOA compared to the control.

\section{Gene Expression of Tight Junction Protein}

Dietary supplemented with LMOA and HMOA increased $(P<$ $0.05)$ the relative expression of Claudin-1, ZO-1, and Claudin-2 in the duodenum of $42 \mathrm{~d}$-broilers compare to the control group. In addition, LMOA- and HMOA-supplemented diets enhanced $(P<0.05)$ the relative expression of Claudin-1 in the jejunum of $42 \mathrm{~d}$-broilers (Figure 4). The addition of LMOA to the diets caused a higher $(P<0.05)$ gene expression of Claudin- 2 in the jejunum and of Occludin, ZO-2, and Claudin-2 in the ileum of 42 d-broilers.

\section{Intestinal Microbiota Composition}

The bacterial community classification of OTUs was performed on the basis of available sequences with $97 \%$ similarity (13). The difference in the $\alpha$-diversity analysis at OTUs levels between the treatment and the control was not noticed (Figure 5). From the Venn analysis of OTUs in cecum digestive of $42 \mathrm{~d}$-broilers (Figure 6A), there were 28, 16, and 24 unique OTUs in the cecum digestive tract in the control, LMOA, and HMOA groups, respectively, and a total of 642 OTUs were common to all group. At the phylum level (Figures 6B,D), the microbiota composition of cecal contents in 42 d-broilers was primarily Firmicutes and Bacteroidetes, which accounted for more than 98.5\%. The populations of Firmicutes in 42 d-broilers fed with HMOA (81.55\%) and the populations of Bacteroidetes (33.88\%) in 42 d-broilers supplemented with LMOA were higher than the control (Firmicutes: 72.35\%; Bacteroidetes: 26.81\%)., respectively. At the family level (Figures 6C,E), the microbiota in the cecum digestive of $42 \mathrm{~d}$-broilers were mainly composed of Ruminococcaceae, Lachnospiraceae, Rikenellaceae, Oscillospiraceae, Erysipelotrichaceae, and Bacteroidaceae, which accounted for beyond $70 \%$.

Principal coordinates analysis ( $\mathrm{PCoA}$ ) based on the distance algorithm of Bray-Curtis calculated from OTUs abundance matrix and the results were examined by statistics acquired from ANOSIM analysis $(R=0.23, P=0.02)$ (Figure 7). 


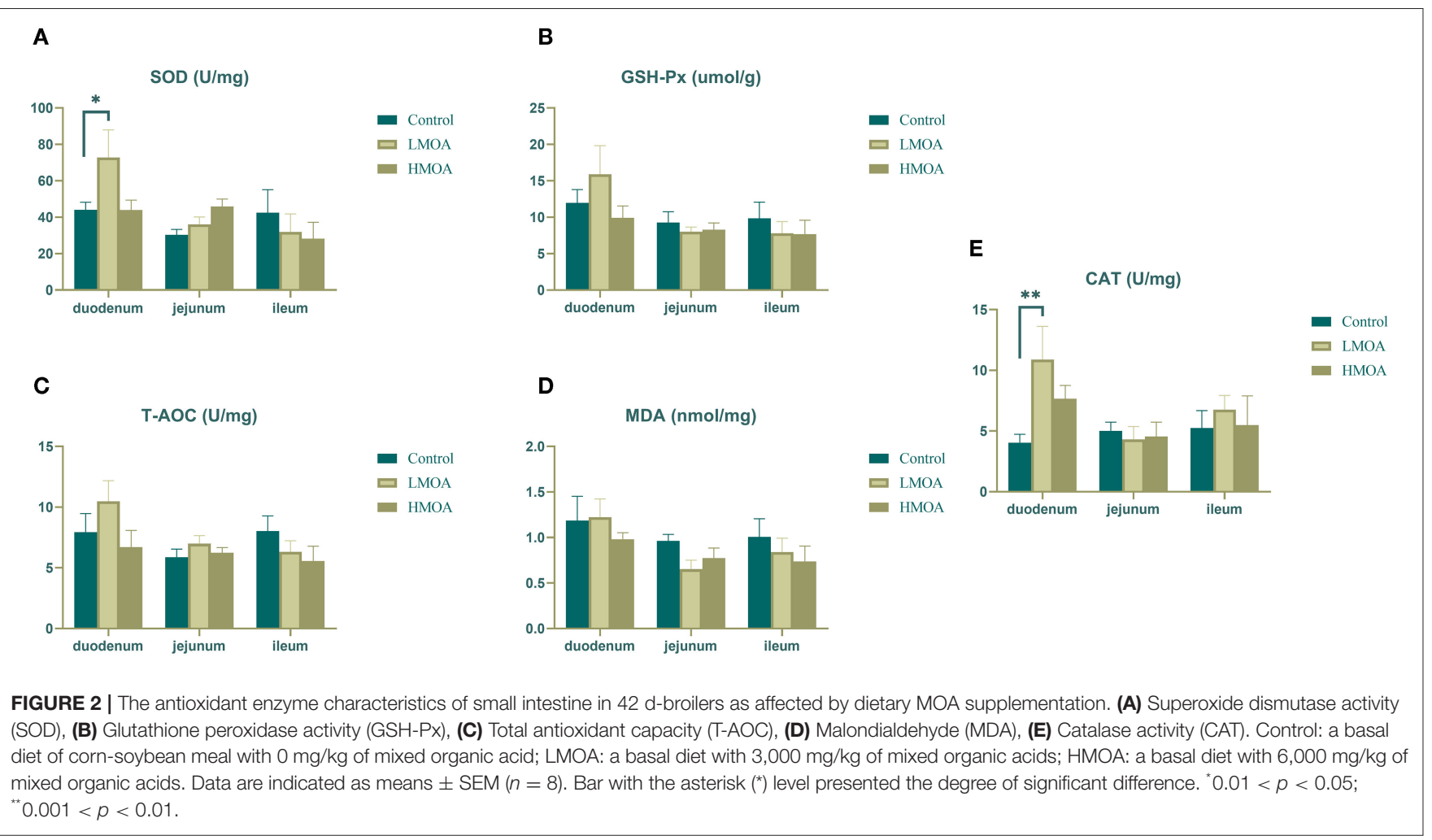



The non-parametric factorial Kruskal-Wallis sum-rank test was used to identify the microorganisms with significant difference characteristics and using linear discriminant analysis (LDA threshold $>2.0$ ) to estimate the magnitude of the effect of 


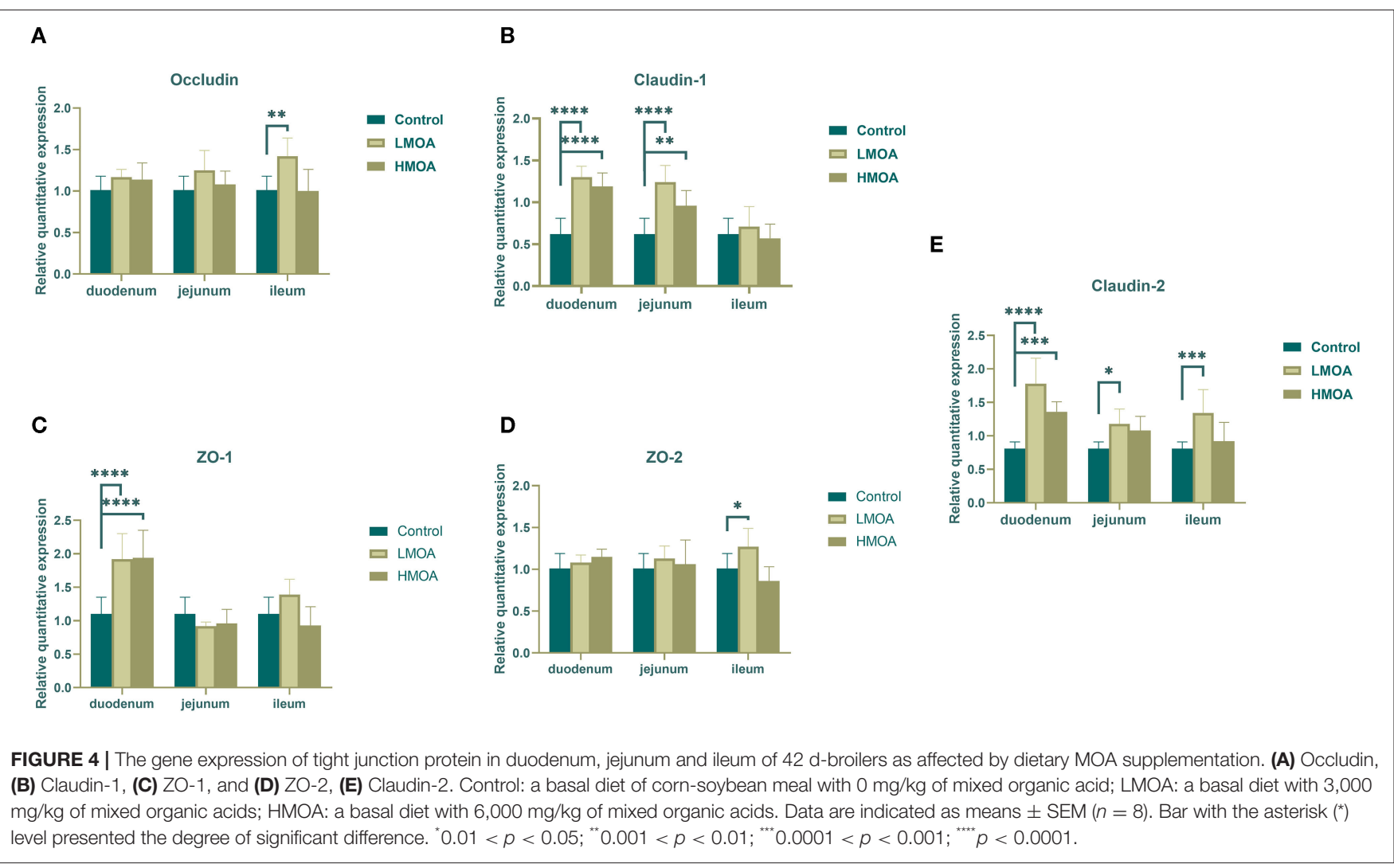

abundance on the difference effect for each species. The results revealed that the microbiota composition in the cecum was affected by feeding modification as well as the enrichment $(P<$ 0.05 ) of Desulfovibrionales order and Desulfovibrionaceae family was observed in the cecum of $42 \mathrm{~d}$-broilers diets with LMOA supplementation. Furthermore, the higher relative abundance of Enterobacteriaceae order and Enterobacterales family were noticed $(P<0.05)$ in the control group.

\section{DISCUSSION}

The previous study has demonstrated that dietary supplemented with mixed organic acid could improve performance (14), immune function $(5,15)$, intestinal morphology as well as intestinal microbiota $(10,16)$. Also, numerous scholars have illustrated the mechanism of MOA and summarized the benefits of MOA in livestock and poultry $(4,17)$, especially in weaning pigs $(7,8)$. The inconsistent results often occurred concerning the effects of MOA, although MOA always performed a positive impact $(18,19)$. In our paper, we focused on the serum immune function, antioxidant capacity, $\mathrm{pH}$ value, tight junction, and microbiota of intestine in 21 and $42 \mathrm{~d}$ broilers in terms of their being affected by dietary supplemented with MOA at different levels, which would be helpful in determining the appropriate level of MOA and in confirming whether MOA plays a role on intestine regarding antioxidant systems, digestive enzyme activity, mechanical barrier, etc.
Lactate is a metabolite of the anaerobic oxidation of glucose (glycolysis) and an essential oxidant of the aerobic metabolic system. It is primarily generated in bone, muscle, brain, and red blood cells. It is transformed into glucose in the liver via the gluconeogenic pathway, which plays a vital role in the energy supply system (20). Measurement of serum lactate level indicates the state of tissue oxygen supply and metabolism as well as inadequate perfusion $(21,22)$. However, excessive levels of lactic acid have a negative effect on the acid-base balance of the organism and trigger metabolic diseases (23). A higher level of D-lactate in the serum of 21 and 42 d-broilers dietary with HMOA supplementation was noticed in our present study, which presumably associated with the composition of the mixed organic acid product containing lactic acid and the concentration of mixed organic acid.

IgG, IgA, and IgM are three essential immunoglobulins, and the immune status could be determined by measuring the level of immunoglobulins in the serum (24). IL-10 is a cytokine with pleiotropic properties in immune regulation and inflammation. It downregulates the expression of Th1 cytokines, MHC-II class antigens, and co-stimulatory molecules on macrophages (25). Likewise, it enhances the survival, proliferation, and antibody production of B cells. IL-10 blocks NF- $\mathrm{KB}$ activity and is involved in the regulation of the JAK-STAT signaling pathway (26). Our findings that dietary HMOA supplementation increased the IgA level were similar to the previous research that mixed organic acid and medium-chain fatty acids combined linear increased the concentration of IgG in serum of broiler. The 


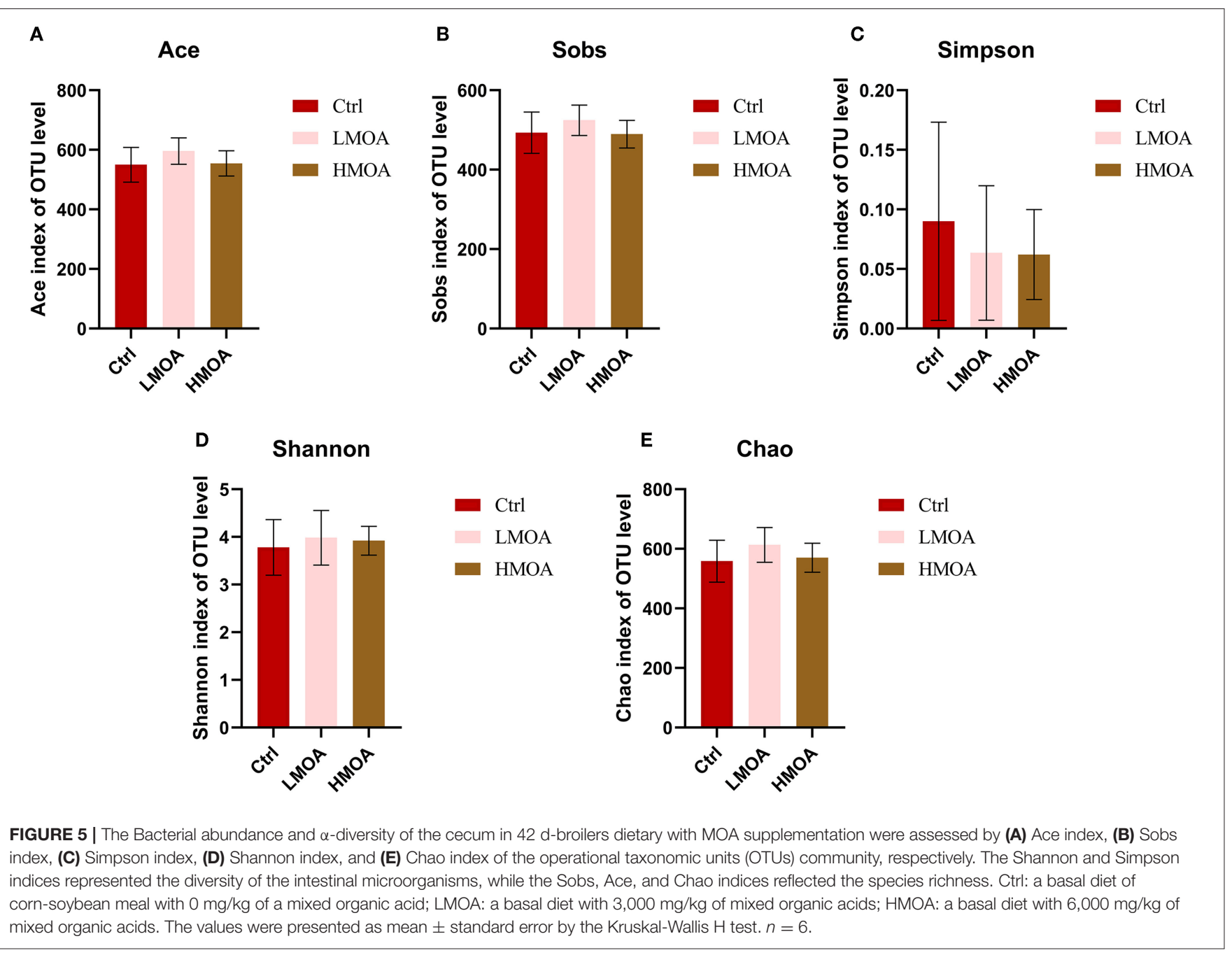

differences may be connected to the ingredients of the diet, the composition, and the combination of the organic acid mix and the broiler breed. It is poorly understood concerning the increase in serum concentrations of IL-10. Still, the latest findings demonstrated that SCFAs increased IL-10 concentrations in T cells and regulatory B cells by inhibiting histone deacetylase from enhancing histone acetylation and regulating the mammalian target of rapamycin (mTOR) $(27,28)$.

The development of the spleen, as an immune organ of poultry, was used as an indicator to evaluate immune performance (29). The pancreas performs a critical role in the process of digestion and absorption of feed nutrients in poultry. The development of the liver is an indicator to assess the metabolic function of poultry. In the present research, the difference was not observed between control and treatments in the spleen, pancreas, and liver of 21 and 42 d-broilers, which inconsistent with the Mohamed et al. (30), they indicated that the broilers fed with organic acid increased the weight of the spleen, the findings of Abdel-Fattah et al. (31) and Ghazalah et al. (32) also supported the conclusion. The reason for the discrepancy is probably related to the composition of the mixed organic acids as well as their concentrations, the specific reason for which is obscure, which needed to be confirmed further.

The digestive tract of poultry is comparatively short, especially in juvenile animals, and the $\mathrm{pH}$ of the small intestine is vulnerable to external environmental factors (4). In principle, mixed organic acids are capable of assisting the digestive tract in maintaining a suitable acidity, which also acts as one of the fundamental mechanisms of mixed organic acids $(3,33)$. Nevertheless, the results that mixed organic acids generally reduce the $\mathrm{pH}$ value of the gastrointestinal tract of animals were widely varied. Ndelekwute et al. (34) demonstrated that the addition of $0.25 \%$ acetic acid and butyric acid to broiler diets, respectively decreased the $\mathrm{pH}$ value of the duodenum and cecum of broilers. However, it has also been found that the diets supplemented with acetic acid, butyric acid, citric acid, or lactic acid had no significant effect on the $\mathrm{pH}$ value of the duodenum, jejunum, and ileum of broilers (35). In our findings, diets with LMOA and HMOA supplementation decreased the $\mathrm{pH}$ value of the duodenum in broilers, but unaffected on other digestive tracts, which indicated that the effect of mixed organic acids on small intestinal $\mathrm{pH}$ was mainly centered in the anterior segment. Still, the results 


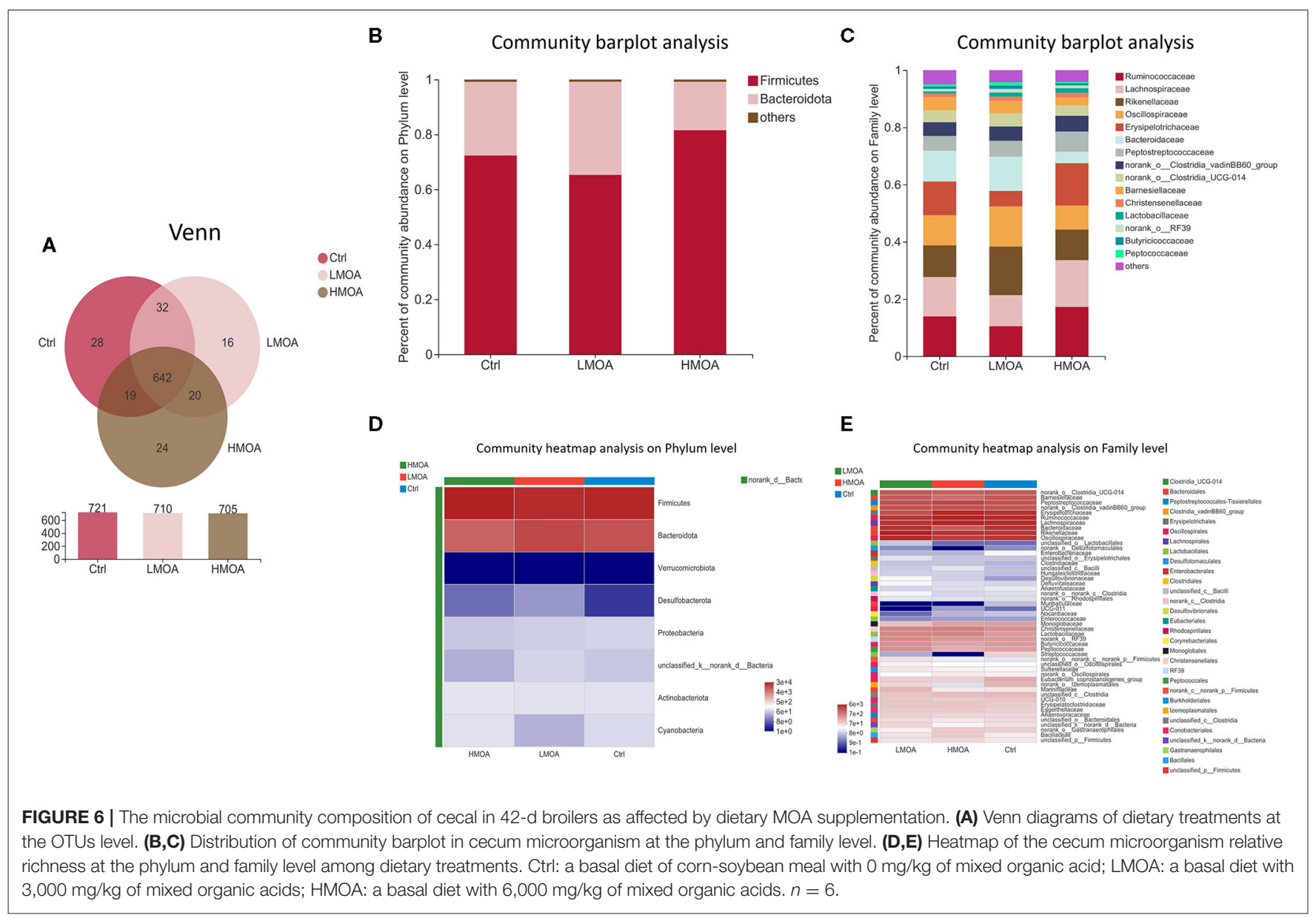

were inconsistent with Paul et al. (36) and Giannenas et al. (37), they reported that $\mathrm{pH}$ remained unaffected supplemented with organic acid salt and benzoic acid combined with essential oil, respectively. The differences may be associated with the metabolism of the mixed organic acid with the consumption of chyme in the digestive tract (35) as well as a possibility that the commercial feeds were formulated with a high buffering capacity to be compatible with the nutritional and energy requirements of modern broilers (38).

The pancreas of poultry exerts trypsin, chymotrypsin, pancreatic amylase, and pancreatic lipase, with amylase, protease, and lipase being the majority and only functioning after entering the small intestine (39). Hence, improved digestibility can be predicted to occur with higher digestive enzyme activity in the intestine or the gut's capability to absorb nutrients (40). In the present study, dietary supplementation with LMOA increased the amylase activity of the pancreas in broilers but at the level of intestinal digestion. No LMOA or HMOA had an impact on the trypsin, lipase, and chymotrypsin activities, which is in line with a study by Palamidi et al. (38), who reported that diets with mixed organic acid did not show an observed difference in the amylase and lipase activities of the small intestine and even decreased the trypsin activity of pancreas in broilers. The results were perhaps associated with the feedback inhibition of proteases in the duodenum according to Li et al. (41). Similarly, the addition of lactic acid to diets did not show any change in digestive enzymes in the pancreas and small intestine of broilers (42). The increased activity of pancreatic lipase may be correlated with the lower $\mathrm{pH}$ of the gastrointestinal tract (43), which was required to confirm further.

Oxidative stress, one of the primary pathological factors affecting animal growth performance (44), is a state of imbalance in the oxidative system owing to the excessive generation and accumulation of reactive oxygen species (ROS) (45). The level of malondialdehyde, as a metabolite of the peroxidation reaction between free radicals and biofilm lipids, directly reflects the degree of tissue peroxidation and indirectly reflects the degree of cell damage caused by oxygen-free radicals. Consequently, animals are well-equipped with basic anti-ROS defense systems to maintain ROS homeostasis (46). Superoxide dismutase (SOD) is an essential antioxidant enzyme that catalyzes the disproportionation of $\mathrm{O}_{2}^{-}$to $\mathrm{O}_{2}$ and $\mathrm{H}_{2} \mathrm{O}_{2}$ and the removal of $\mathrm{O}_{2}^{-}$from the mitochondrial membrane and mitochondrial matrix, often regarded as an indicator of the ability to respond to oxidative stress. Glutathione peroxidase (GSH-Px) is involved in converting between reduced glutathione and oxidized glutathiol, reduced $\mathrm{H}_{2} \mathrm{O}_{2}$ to $\mathrm{H}_{2} \mathrm{O}$, and lipid peroxides to alcohols. Total antioxidant capacity (T-AOC) was used as an indicator of 


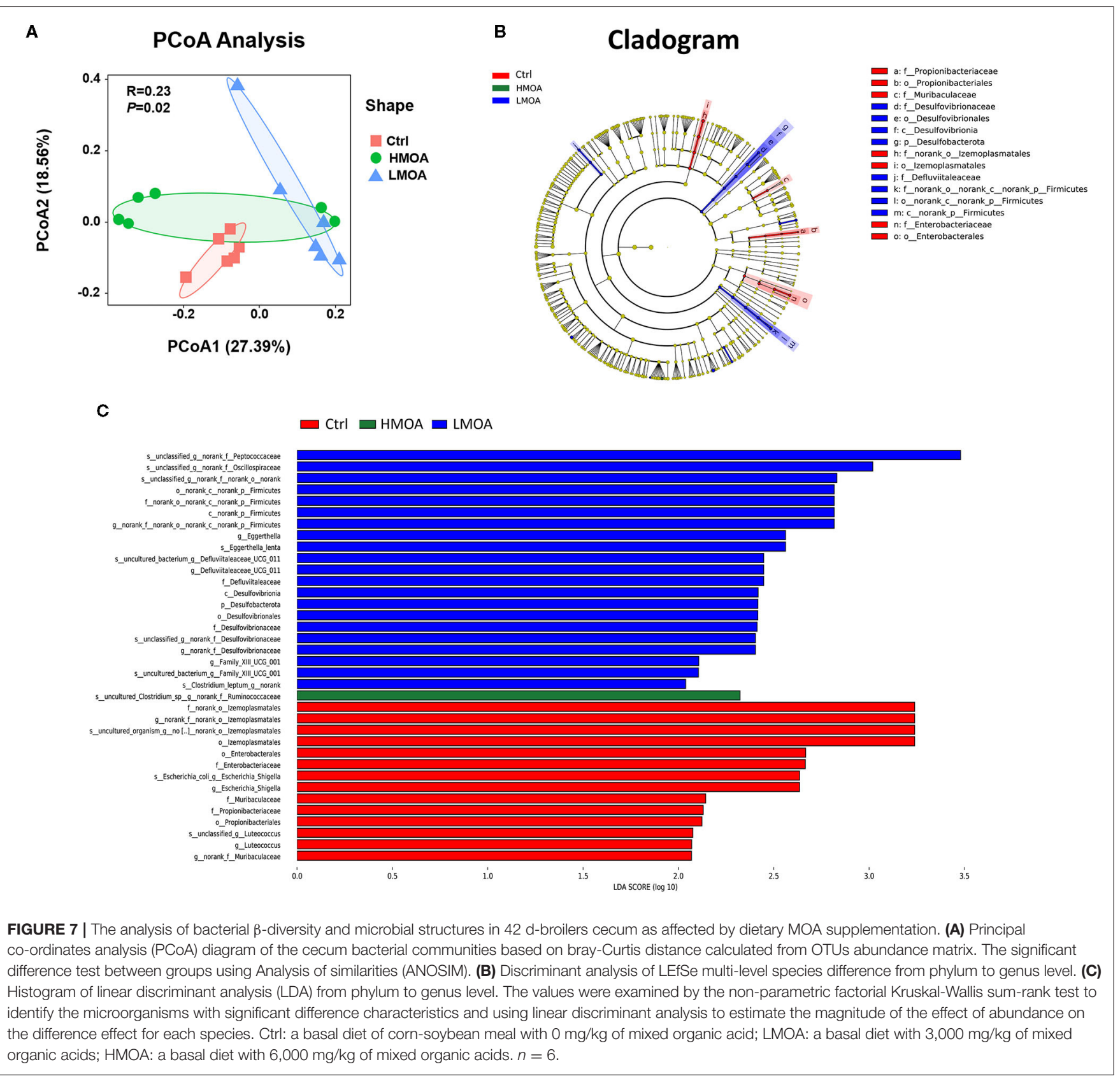

the overall antioxidant capacity of the organism $(47,48)$. In our research, diets with HMOA supplementation enhanced the content of SOD and CAT in the serum of 21 and 42 d-broiler, respectively, and the level of T-AOC, SOD, and CAT were increased in serum of $42 \mathrm{~d}$-broiler fed with LMOA. Additionally, an improvement of the SOD and CAT were observed in the duodenum of broilers supplemented with LMOA, which corresponded with Abudabos et al. (49), who reported that dietary organic acid enhanced the T-AOC and lowered the concentration of $\mathrm{H}_{2} \mathrm{O}_{2}$ in serum to reduce the oxidative stress status of 42 d-broilers. Likewise, diets supplemented with organic acid and Bacillus subtilis combination improved the concentration of T-AOC in the serum of broilers challenged with Salmonella typhimurium (50). Besides, citric acid and malic acid were discovered to have a robust antioxidative capacity by Tezcan et al. (51). However, with the exception of the duodenum, there was no significant modification of the antioxidant index in the jejunum and ileum, which was probably attributed to the fact that the mixed organic acids only served in the stomach and duodenum and were unable to completely reached and act in the posterior intestinal tract $(3,33)$. Therefore, it is desirable to upgrade the production technology (e.g., microencapsulation), 
making it available for the mixed organic acids to perform continuously and stably in the entire intestinal segment of broilers as well as improving the antioxidant function of broilers.

The function of the intestinal mechanical barrier is a precondition for upholding the homeostasis of mucosal function while sustaining the capacity to absorb nutrients (52). The tight junction is the primary intercellular junction positioned at the tip of the epithelium and surrounding the cells in a hoop-like fashion, which tightly connects adjacent epithelial cells, preventing the passage of toxic macromolecules and microorganisms and defending the intestinal mucosal barrier. The tight junction was classified into structural and functional proteins, the principal structural proteins are occludin, Claudin and junction adhesion molecule (JAM) and the main functional proteins are Z0-1, Z0-2, Z0-3, Cingulin, and Zonulin (53). In this work, we demonstrated that dietary supplementation with the LMOA and HMOA enhanced the expression of tight junction (mainly Claudin-1, Claudin-2, and ZO-1) in the small intestine, respectively; to some extent, the broilers fed with LMOA performed better than the HMOA group. Identical conclusions were obtained by Yang et al. (54), they indicated that dietary supplemented encapsulated organic acids increased the Claudin1 mRNA expression, and numerous studies have also been verified in other animals that the expression of tight junction proteins in the small intestine of animals was enhanced by organic acids (55-58). Therefore, mixed organic acids regulated the mechanical barrier of the animal intestine and defended the intestine from exposure to direct pathogenic bacteria mainly by elevating the expression of genes associated with tight junction proteins Claudin, Occludin, and Z0s in the intestine.

The intestinal microorganisms performed a key nutritional, immune, and regulatory role in host metabolism, and dysbiosis of the bacteria triggered a range of diseases. For example, acute enteritis has been proved to be correlated with specific pathogenic intestinal dominant bacteria (59). Variations in the intestinal microorganisms were indicative of the status of the intestinal bacteria. The results of our present study revealed that the supplementation of diets with mixed organic acids seems to be dose-dependent on the intestinal microbial structure of broiler cecum, which should be validated with statistics analysis.

Normally, the diversity of microorganisms is positively correlated with the capacity to equilibrate the structure of the intestinal microorganisms and to resist colonization by foreign pathogens. The diversity and richness of the intestinal microorganisms decrease when the organism undergoes disease (60). In our paper, diet supplementation with LMOA increased the Chao, Shannon, Sobs, and Ace indices, but this did not show a significantly observable difference; the differences occurred may be associated with the breeds and ages of broilers as well as the composition of mixed organic acids (61).

It has been shown that Bacteroidetes and Firmicutes constitute the majority of the microbial community at the phylum level in broilers, which performed a paramount role in energy production and metabolism (62-64). Notably, Firmicutes has been reported as the dominant phylum in the chicken cecum community $(65,66)$, while Bacteroidetes was also reported as the dominant phylum $(64,67)$. In this study, there was no significant difference in the relative abundance of broiler cecum microorganisms at the phylum level among the treatments. The Bacteroidetes and Firmicutes were the dominant bacteria, accounting for more than $98.5 \%$ of the total microbial community, and the Firmicutes occupied the maximum percentage. The reasons for the differences that appeared might be attributed to the age and breed of the selected chickens as well as regional differences (68), which also indicated that the microbiota of the broiler cecum was being modified.

Ruminococcaceae are capable of generating short-chain fatty acids, which could inhibit the growth and reproduction of pathogenic intestinal bacteria by impacting the intestinal $\mathrm{pH}$, which is a prerequisite and guarantee for achieving a good growth performance in broilers $(69,70)$. This is in accordance with our findings of the enhanced relative abundance of Ruminococcaceae in cecum broilers fed with HMOA. Sulfatereducing bacteria of the family Desulfovibacteriaceae consume short-chain fatty acids, which are crucial for intestinal epithelial cells, caused damage to intestinal epithelial cells by producing $\mathrm{H}_{2} \mathrm{~S}$ (71-73), and their lipopolysaccharides have a stronger ability to trigger inflammation (74). So, Desulfovibacteriaceae might be a functional bacterium with a vital role in the intestine and possibly played an essential character in developing metabolic syndrome. Consequently, the increased relative abundance of Desulfovibacteriaceae in the LMOA group in this study may not be a favorable phenomenon, an occurrence that requires further confirmation. In addition, a higher relative abundance of Escherichia coli was noted in the control group, which indicated diet supplemented with mixed organic acid promoted intestine health by reducing harmful pathogenic bacteria, which were identified by numerous broilers studies (19).

\section{CONCLUSIONS}

In summary, our findings demonstrated the beneficial impacts of the broiler dietary supplementation with mixed organic acid enhanced the immune characteries and antioxidative function in serum and small intestine, promoted the digestive enzyme activity of the pancreas, improved the expression of tight junction proteins, and modulated the cecum bacterial community, which achieves a better healthy growth for broilers. However, there are still some unknown questions remaining to be solved such as the increased relative abundance of Desulfovibacteriaceae in cecum broilers diets with LMOA. Therefore, additional relevant research may contribute to the resolution of this phenomenon. In addition, considering the overall effect of the experiment and the economic cost, it is feasible to supplement the diet with mixed organic acid at $3,000 \mathrm{mg} / \mathrm{kg}$ to promote the antioxidant characteristics and health status of broilers.

\section{DATA AVAILABILITY STATEMENT}

The original contributions presented in this study are included in the article/supplementary material, further inquiries can be directed to the corresponding author/s. 


\section{ETHICS STATEMENT}

The animal study was reviewed and approved by the Institutional Animal Care and Use Committee of China Agricultural University (No.AW09089104-1, Beijing, China).

\section{AUTHOR CONTRIBUTIONS}

JM, XP, and SM: conceptualization. JM, XP, and JW: methodology. JM: software, investigation, data curation, and writing-original draft preparation. JM, SM, and JW: validation and resources. JM and JW: formal analysis. SM and XP: writing-review and editing, and supervision. XP: project administration and funding acquisition. All authors contributed to the article and approved the submitted version.

\section{REFERENCES}

1. Organization World Health. The Evolving Threat of Antimicrobial Resistance. Options for Action. Switzerland: World Health Organization Press (2012).

2. Dibner JJ, Richards JD. Antibiotic growth promoters in agriculture: history and mode of action. Poultry Sci. (2005) 84:634-43. doi: 10.1093/ps/84.4.634

3. Liu YH, Espinosa CD, Abelilla JJ, Casas GA, Lagos LV, Lee SA, et al. Nonantibiotic feed additives in diets for pigs: a review. Anim Nutr. (2018) 4:11325. doi: 10.1016/j.aninu.2018.01.007

4. Gadde U, Kim WH, Oh ST, Lillehoj HS. Alternatives to antibiotics for maximizing growth performance and feed efficiency in poultry: a review. Anim Health Res Rev. (2017) 18:26-45. doi: 10.1017/S1466252316000207

5. Long SF, Xu YT, Pan L, Wang QQ, Wang CL, Wu JY, et al. Mixed organic acids as antibiotic substitutes improve performance, serum immunity, intestinal morphology and microbiota for weaned piglets. Anim Feed Sci Tech. (2018) 235:23-32. doi: 10.1016/j.anifeedsci.2017.08.018

6. Li M, Long SF, Wang QQ, Zhang LH, Hu JX, Yang J, et al. Mixed organic acids improve nutrients digestibility, volatile fatty acids composition and intestinal microbiota in growing-finishing pigs fed high-fiber diet. Asian Austral J Anim. (2019) 32:856-64. doi: 10.5713/ajas.18.0517

7. Xu Y, Lahaye L, He Z, Zhang J, Yang C, Piao X. Micro-encapsulated essential oils and organic acids combination improves intestinal barrier function, inflammatory responses and microbiota of weaned piglets challenged with

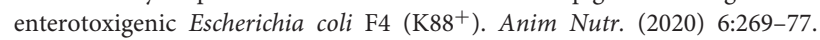
doi: 10.1016/j.aninu.2020.04.004

8. Xu YT, Liu L, Long SF, Pan L, Piao XS. Effect of organic acids and essential oils on performance, intestinal health and digestive enzyme activities of weaned pigs. Anim Feed Sci Tech. (2018) 235:110-9. doi: 10.1016/j.anifeedsci.2017.10.012

9. Stamilla A, Messina A, Sallemi S, Condorelli L, Antoci F, Puleio R, et al. Effects of microencapsulated blends of organics acids (OA) and essential oils (EO) as a feed additive for broiler chicken. A focus on growth performance, gut morphology and microbiology. Animals. (2020) 10:442. doi: 10.3390/ani10030442

10. Pham VH, Kan LG, Huang JY, Geng YQ, Zhen WR, Guo YM, et al. Dietary encapsulated essential oils and organic acids mixture improves gut health in broiler chickens challenged with necrotic enteritis. J Anim Sci Biotechno. (2020) 11:18. doi: 10.1186/s40104-019-0421-y

11. Zhang S, Shen YR, Wu S, Xiao YQ, He Q, Shi SR. The dietary combination of essential oils and organic acids reduces Salmonella enteritidis in challenged chicks. Poultry Sci. (2019) 98:6349-55. doi: 10.3382/ps/pez457

12. Stackebrandt E, Goebel BM. A place for dna-dna reassociation and $16 \mathrm{~s}$ ribosomal-RNA sequence-analysis in the present species definition in bacteriology. Int J Syst Bacteriol. (1994) 44:846-9. doi: 10.1099/00207713-44-4-846

13. Edgar RC. UPARSE: highly accurate OTU sequences from microbial amplicon reads. Nat Methods. (2013) 10:996. doi: 10.1038/nmeth.2604

\section{FUNDING}

This research was funded by the National Natural Science Foundation of China (31772612), the Beijing Municipal Natural Science Foundation (6202019).

\section{ACKNOWLEDGMENTS}

The authors acknowledge the Ministry of Agriculture Feed Industry Center (MAFIC) at China Agricultural University for providing the experimental poultry house and the Nutreco company (Amersfoort Netherland) for supplying the new MOA commercial products.

14. Galli GM, Aniecevski E, Petrolli TG, da Rosa G, Boiago MM, Simoes CADP, et al. Growth performance and meat quality of broilers fed with microencapsulated organic acids. Anim Feed Sci Tech. (2021) 271:114706. doi: 10.1016/j.anifeedsci.2020.114706

15. Janghan C, Wang L, Liu S, Lu P, Zhao X, Liu H, et al. Effects of a microencapsulated formula of organic acids and essential oils on nutrient absorption, immunity, gut barrier function, and abundance of enterotoxigenic Escherichia coli F4 in weaned piglets challenged with E. coli F4. J Anim Sci. (2020) 98:skaa259. doi: 10.1093/jas/skaa259

16. Dai D, Qiu K, Zhang H-j, Wu S-g, Han Y-m, Wu Y-y, et al. Organic acids as alternatives for antibiotic growth promoters alter the intestinal structure and microbiota and improve the growth performance in broilers. Front Microbiol. (2021) 11:618144. doi: 10.3389/fmicb.2020.618144

17. Khan SH, Iqbal J. Recent advances in the role of organic acids in poultry nutrition. J Appl Anim Res. (2016) 44:359-69. doi: 10.1080/09712119.2015.1079527

18. Wang MM, Huang HJ, Hu YP, Liu YT, Zeng X, Zhuang Y, et al. Effects of dietary supplementation with herbal extract mixture on growth performance, organ weight and intestinal morphology in weaning piglets. J Anim Physiol Anim Nutr. (2020) 104:1462-70. doi: 10.1111/jpn.13422

19. Emami NK, Daneshmand A, Naeini SZ, Graystone EN, Broom LJ. Effects of commercial organic acid blends on male broilers challenged with E-coli K88: performance, microbiology, intestinal morphology, and immune response. Poultry Sci. (2017) 96:3254-63. doi: 10.3382/ps/pex106

20. Brooks GA. Lactate production under fully aerobic conditions - the lactate shuttle during rest and exercise. Fed Proc. (1986) 45:2924-9.

21. Iles RA, Cohen RD, Rist AH, Baron PG. Mechanism of inhibition by acidosis of gluconeogenesis from lactate in rat-liver. Biochem J. (1977) 164:185-91. doi: 10.1042/bj1640185

22. Wardi G, Brice J, Correia M, Liu D, Self M, Tainter C. Demystifying lactate in the emergency department. Ann Emerg Med. (2020) 75:557. doi: 10.1016/j.annemergmed.2019.06.027

23. Chen H, Zhao CY, Wei Y, Jin J. Early lactate measurement is associated with better outcomes in septic patients with an elevated serum lactate level. Crit Care. (2019) 23:351. doi: 10.1186/s13054-01 9-2625-0

24. Insoft RM, Sanderson IR, Walker WA. Development of immune function in the intestine and its role in neonatal diseases. Pediatr Clin N Am. (1996) 43:551. doi: 10.1016/S0031-3955(05)70420-X

25. Malefyt RD, Haanen J, Spits H, Roncarolo MG, Tevelde A, Figdor C, et al. Interleukin-10 (il-10) and viral-il-10 strongly reduce antigen-specific human t-cell proliferation by diminishing the antigen-presenting capacity of monocytes via down-regulation of class-ii major histocompatibility complex expression. J ExP Med. (1991) 174:915-24. doi: 10.1084/jem.174.4.915

26. Moore KW, Malefyt RD, Coffman RL, O'Garra A. Interleukin-10 and the interleukin-10 receptor. Annu Rev Immunol. (2001) 19:683-765. doi: 10.1146/annurev.immunol.19.1.683 
27. Sun MM, Wu W, Chen L, Yang WJ, Huang XS, Ma CY, et al. Microbiotaderived short-chain fatty acids promote Th1 cell IL-10 production to maintain intestinal homeostasis. Nat Communs. (2018) 9:3555. doi: 10.1038/s41467-018-05901-2

28. Luu M, Visekruna A. Short-chain fatty acids: bacterial messengers modulating the immunometabolism of T cells. Eur J Immunol. (2019) 49:842-8. doi: 10.1002/eji.201848009

29. Liu L, Shen J, Zhao C, Wang XF, Yao JH, Gong YS, et al. Dietary Astragalus polysaccharide alleviated immunological stress in broilers exposed to lipopolysaccharide. Int J Biol Macromol. (2015) 72:624-32. doi: 10.1016/j.ijbiomac.2014.08.057

30. Mohamed MA, El-Daly EF, Abd el-Azeem N, Youssef A, Hassan HMA. Growth performance and histological changes in ileum and immune related organs of broilers fed organic acids or antibiotic growth promoter. Int J Poult Sci. (2014) 13:602-10. doi: 10.3923/ijps.2014.602.610

31. Abdel-Fattah S, M.H E-S, El-Medany N, Abdelazeem F. Thyroid activity, some blood constituents, organs morphology and performance of broiler chicks fed supplemental organic acids. Int J Poult Sci. (2008) 7:215-22. doi: 10.3923/ijps.2008.215.222

32. Ghazalah AA, Atta AM, Elkloub K, Moustafa MEL, Shata Riry FH. Effect of dietary supplementation of organic acids on performance, nutrients digestibility and health of broiler chicks. Int J Poult Sci. (2011) 10:176-84. doi: 10.3923/ijps.2011.176.184

33. Suiryanrayna M, Ramana JV. A review of the effects of dietary organic acids fed to swine. J Anim Sci Biotechno. (2015) 6:45. doi: 10.1186/s40104-015-0042-z

34. Ndelekwute EK, Unah UL, Udoh UH. Effect of dietary organic acids on nutrient digestibility, faecal moisture, digesta $\mathrm{pH}$ and viscosity of broiler chickens. MOJAP. (2019) 6:40-3. doi: 10.15406/mojap.2019.06. 00242

35. Mahdavi R, Torki M. Study on usage period of dietary protected butyric acid on performance, carcass characteristics, serum metabolite levels and humoral immune response of broiler chickens. J Anim Vet Adv. (2009) 8:1702-9. doi: 10.1016/j.fsi.2009.06.017

36. Paul S, Halder G, Mondal M, Samanta G. Effect of organic acid salt on the performance and gut health of broiler chicken. J Poult Sci. (2007) 44:389-95. doi: 10.2141 /jpsa.44.389

37. Giannenas IA, Papaneophytou CP, Tsalie E, Triantafillou E, Tontis D, Kontopidis GA. The effects of benzoic acid and essential oil compounds in combination with protease on the performance of chickens. J Anim Feed Sci. (2014) 23:73-81. doi: 10.22358/jafs/65719/2014

38. Palamidi I, Paraskeuas V, Theodorou G, Breitsma R, Schatzmayr G, Theodoropoulos G, et al. Effects of dietary acidifier supplementation on broiler growth performance, digestive and immune function indices. Anim Prod Sci. (2017) 57:271-81. doi: 10.1071/AN15061

39. Osman AM, Tanios NI. The effect of heat on the intestinal and pancreatic levels of amylase and maltase of laying hens and broilers. ComP Biochem Phys A. (1983) 75:563-7. doi: 10.1016/0300-9629(83)90421-8

40. Rideau N, Nitzan Z, Mongin P. Activities of amylase, trypsin and lipase in the pancreas and small-intestine of the laying hen during egg formation. Brit Poultry Sci. (1983) 24:1-9. doi: 10.1080/00071668308416707

41. Li Y, Hao YB, Owyang C. Diazepam-binding inhibitor mediates feedback regulation of pancreatic secretion and postprandial release of cholecystokinin. J Clin Invest. (2000) 105:351-9. doi: 10.1172/JCI7204

42. Jang IS, Ko YH, Yang HY, Ha JS, Kim JY, Kim JY, et al. Influence of essential oil components on growth performance and the functional activity of the pancreas and small intestine in broiler chickens. Asian Austral J Anim. (2004) 17:394-400. doi: 10.5713/ajas.2004.394

43. Thaela M-j, Jensen MS, Pierzynowski S, Jakob S, Jensen B. Effect of lactic acid supplementation on pancreatic secretion in pigs after weaning. J Anim Feed Sci. (1998) 7(Suppl. 1):181-3. doi: 10.22358/jafs/69972/1998

44. Mruk DD, Silvestrini B, Mo MY, Cheng CY. Antioxidant superoxide dismutase - a review: its function, regulation in the testis, and role in male fertility. ContracePtion. (2002) 65:305-11. doi: 10.1016/S0010-7824(01)00320-1

45. Hussain T, Tan B, Yin YL, Blachier F, Tossou MCB, Rahu N. Oxidative stress and inflammation: what polyphenols can do for us? Oxid Med Cell Longev. (2016) 2016:7432797. doi: 10.1155/2016/7432797
46. Yang Y, Zhang L, Jiang G, Lei A, Yu Q, Xie J, et al. Evaluation of protective effects of Ganoderma atrum polysaccharide on Acrylamideinduced injury in rats small intestine tissue. Food Funct. (2019) 10:5863-72. doi: 10.1039/C9FO01452G

47. Li SY, Wu BN, Fu WY, Reddivari L. The anti-inflammatory effects of dietary anthocyanins against ulcerative colitis. Int J Mol Sci. (2019) 20:2588. doi: 10.3390/ijms20102588

48. Moine L, Rivoira M, de Barboza GD, Perez A, de Talamoni NT. Glutathione depleting drugs, antioxidants and intestinal calcium absorption. World J Gastroentero. (2018) 24:4979-88. doi: 10.3748/wjg.v24.i4 4.4979

49. Abudabos AM, Al-Mufarrej SI. Effects of organic acid supplementation on antioxidant capacity and immune responses of broilers challenged orally with Salmonella enterica subsp enterica Typhimurium. S Afr J Anim Sci. (2014) 44:342-9. doi: 10.4314/sajas.v44i4.4

50. Abudabos AM, Alyemni AH, Dafalla YM, Khan RU. Effect of organic acid blend and Bacillus subtilis alone or in combination on growth traits, blood biochemical and antioxidant status in broilers exposed to Salmonella typhimurium challenge during the starter phase. J Appl Anim Res. (2017) 45:538-42. doi: 10.1080/09712119.2016.1219665

51. Tezcan F, Gultekin-Ozguven M, Diken T, Ozcelik B, Erim FB. Antioxidant activity and total phenolic, organic acid and sugar content in commercial pomegranate juices. Food Chem. (2009) 115:873-7. doi: 10.1016/j.foodchem.2008.12.103

52. Sánchez de Medina F, Romero-Calvo I, Mascaraque C, Martinez O. Intestinal inflammation and mucosal barrier function. Inflamm Bowel Dis. (2014) 20:2394-404. doi: 10.1097/MIB.0000000000000204

53. Heinemann U, Schuetz A. Structural features of tight-junction proteins. Int J Mol Sci. (2019) 20:6020. doi: 10.3390/ijms20236020

54. Yang X, Liu YL, Yan F, Yang CB, Yang XJ. Effects of encapsulated organic acids and essential oils on intestinal barrier, microbial count, and bacterial metabolites in broiler chickens. Poultry Sci. (2019) 98:2858-65. doi: $10.3382 / \mathrm{ps} / \mathrm{pez} 031$

55. Ma X, Fan PX, Li LS, Qiao SY, Zhang GL, Li DF. Butyrate promotes the recovering of intestinal wound healing through its positive effect on the tight junctions. J Anim Sci. (2012) 90:266-8. doi: 10.2527/jas.50965

56. Huang C, Song PX, Fan PX, Hou CL, Thacker P, Ma X. Dietary sodium butyrate decreases postweaning diarrhea by modulating intestinal permeability and changing the bacterial communities in weaned piglets. $J$ Nutr. (2015) 145:2774-80. doi: 10.3945/jn.115.217406

57. Tong LC, Wang Y, Wang ZB, Liu WY, Sun S, Li L, et al. Propionate ameliorates dextran sodium sulfate-induced colitis by improving intestinal barrier function and reducing inflammation and oxidative stress. Front Pharmacol. (2016) 7:253. doi: 10.3389/fphar.2016.00253

58. Bai ZG, Zhang ZT, Ye YJ, Wang S. Sodium butyrate induces differentiation of gastric cancer cells to intestinal cells via the PTEN/phosphoinositide 3-kinase pathway. Cell Biol Int. (2010) 34:1141-5. doi: 10.1042/CBI20090481

59. Van Limbergen J, Wilson DC, Satsangi J. The genetics of crohn's disease. Annu Rev Genom Hum G. (2009) 10:89-116. doi: 10.1146/annurev-genom-082908-150013

60. Lin HV, Frassetto A, Kowalik EJ, Nawrocki AR, Lu MFM, Kosinski $\mathrm{JR}$, et al. Butyrate and propionate protect against diet-induced obesity and regulate gut hormones via free fatty acid receptor 3-independent mechanisms. PLoS ONE. (2012) 7:e35240. doi: 10.1371/journal.pone. 0035240

61. Ballou AL, Ali RA, Mendoza MA, Ellis JC, Hassan HM, Croom WJ, et al. Development of the chick microbiome: how early exposure influences future microbial diversity. Front Vet Sci. (2016) 3:2. doi: 10.3389/fvets.2016.00002

62. Ahir V, Koringa P, Bhatt V, Ramani U, Tripathi A, Singh K, et al. Metagenomic analysis of poultry gut microbes. Indian J Poultry Sci. (2010) 45:1114. Available online at: https://www.researchgate.net/publication/216184082_ Metagenomic_analysis_of_poultry_gut_microbes

63. Oakley BB, Lillehoj HS, Kogut MH, Kim WK, Maurer JJ, Pedroso A, et al. The chicken gastrointestinal microbiome. Fems Microbiol Lett. (2014) 360:100-12. doi: 10.1111/1574-6968.12608

64. Pandit RJ, Hinsu AT, Patel NV, Koringa PG, Jakhesara SJ, Thakkar JR, et al. Microbial diversity and community composition of caecal microbiota in commercial and indigenous Indian chickens determined 
using 16s rDNA amplicon sequencing. Microbiome. (2018) 6:115. doi: 10.1186/s40168-018-0501-9

65. Awad WA, Mann E, Dzieciol M, Hess C, Schmitz-Esser S, Wagner M, et al. Age-related differences in the luminal and mucosa-associated gut microbiome of broiler chickens and shifts associated with campylobacter jejuni infection. Front Cell Infect Mi. (2016) 6:154. doi: 10.3389/fcimb.2016.00154

66. Mancabelli L, Ferrario C, Milani C, Mangifesta M, Turroni F, Duranti S, et al. Insights into the biodiversity of the gut microbiota of broiler chickens. Environ Microbiol. (2016) 18:4727-38. doi: 10.1111/1462-2920.13363

67. Shaufi MAM, Sieo CC, Chong CW, Gan HM, Ho YW. Deciphering chicken gut microbial dynamics based on high-throughput $16 \mathrm{~S}$ rRNA metagenomics analyses. Gut Pathog. (2015) 7:4. doi: 10.1186/s13099-015-0051-7

68. Pourabedin M, Zhao X. Prebiotics and gut microbiota in chickens. Fems Microbiol Lett. (2015) 362:fnv122. doi: 10.1093/femsle/fnv122

69. Nava GM, Stappenbeck TS. Diversity of the autochthonous colonic microbiota. Gut Microbes. (2011) 2:99-104. doi: 10.4161/gmic.2.2.15416

70. Zeng XL, Gao XX, Peng Y, Wu QH, Zhu JJ, Tan CH, et al. Higher risk of stroke is correlated with increased opportunistic pathogen load and reduced levels of butyrate-producing bacteria in the gut. Front Cell Infect Mi. (2019) 9:4. doi: 10.3389/fcimb.2019.00004

71. Donohoe DR, Garge N, Zhang XX, Sun W, O'Connell TM, Bunger $\mathrm{MK}$, et al. The microbiome and butyrate regulate energy metabolism and autophagy in the mammalian colon. Cell Metab. (2011) 13:517-26. doi: 10.1016/j.cmet.2011.02.018

72. Roediger WEW, Duncan A, Kapaniris O, Millard S. Reducing sulfur-compounds of the colon impair colonocyte nutrition implications for ulcerative-colitis. Gastroenterology. (1993) 104:802-9. doi: 10.1016/0016-5085(93)91016-B
73. Szabo C. Hydrogen sulphide and its therapeutic potential. Nat Rev Drug Discov. (2007) 6:917-35. doi: 10.1038/ $\operatorname{nrd} 2425$

74. Weglarz L, Parfiniewicz B, Mertas A, Kondera-Anasz Z, Jaworska-Kik M, Dzierzewicz Z, et al. Effect of endotoxins isolated from Desulfovibrio desulfuricans soil and intestinal strain on the secretion of TNF-alpha by human mononuclear cells. Pol J Environ Stud. (2006) 15:615-22. Available online at: http://www.pjoes.com/Effect-of-Endotoxins-IsolatedfromDesulfovibrio-desulfuricans-Soil-and-Intestinal,87912,0,2.html

Conflict of Interest: The authors declare that the research was conducted in the absence of any commercial or financial relationships that could be construed as a potential conflict of interest.

Publisher's Note: All claims expressed in this article are solely those of the authors and do not necessarily represent those of their affiliated organizations, or those of the publisher, the editors and the reviewers. Any product that may be evaluated in this article, or claim that may be made by its manufacturer, is not guaranteed or endorsed by the publisher.

Copyright $\odot 2021$ Ma, Mahfuz, Wang and Piao. This is an open-access article distributed under the terms of the Creative Commons Attribution License (CC BY). The use, distribution or reproduction in other forums is permitted, provided the original author(s) and the copyright owner(s) are credited and that the original publication in this journal is cited, in accordance with accepted academic practice. No use, distribution or reproduction is permitted which does not comply with these terms. 